\title{
Producing Biofuels in Low-Income Countries: An Integrated Environmental and Economic Assessment for Tanzania
}

\author{
James Thurlow • Giacomo Branca • Erika Felix • \\ Irini Maltsoglou • Luis E. Rincón
}

Accepted: 16 December 2014 / Published online: 8 January 2015

C Springer Science+Business Media Dordrecht 2015

\begin{abstract}
This paper jointly evaluates the greenhouse gas emissions and economic impacts from producing biofuels in Tanzania. Sequentially-linked models capture natural resource constraints; emissions from land use change; economywide growth linkages; and household poverty. Results indicate that there are economic incentives to convert unused lands to sugarcane-ethanol production, but only grasslands (not forests) have a reasonable carbon payback period. There are also strong socioeconomic reasons to involve smallholders in feedstock production in order to reduce rural poverty, especially since our results indicate that biofuels have little effect on food production. Yet smallholders require more land than large-scale plantations and so face more binding natural resource and emissions constraints. Overall, environmental constraints alter the socioeconomically optimal biofuel strategy for Tanzania by limiting potential poverty reduction. Unlike previous studies, our integrated assessment suggests that a mixed farming system with greater emphasis on large-scale plantations is more appropriate for producing sugarcane-ethanol in Tanzania.
\end{abstract}

Keywords Biofuels · Economic growth · Greenhouse gas emissions · Poverty · Tanzania

\author{
J. Thurlow $(\bowtie)$ \\ International Food Policy Research Institute, 2033 K Street NW, Washington, DC 20006, USA \\ e-mail: j.thurlow@cgiar.org \\ J. Thurlow \\ United Nations University - World Institute for Development Economics Research, \\ Katajanokanlaituri 6 B, 00160 Helsinki, Finland \\ G. Branca · E. Felix · I. Maltsoglou · L. E. Rincón \\ Food and Agriculture Organization (FAO), Rome, Italy \\ e-mail: giacomo.branca@fao.org \\ E. Felix \\ e-mail: erika.felix@fao.org \\ I. Maltsoglou \\ e-mail: irini.maltsoglou@fao.org \\ L. E. Rincón \\ e-mail: luis.rincon@fao.org
}


Abbreviations

$\begin{array}{ll}\text { BIOTA } & \text { Bioenergy techno-economic analysis } \\ \text { CGE } & \text { Computable general equilibrium } \\ \text { EX-ACT } & \text { Ex ante appraisal carbon-balance tool } \\ \text { GDP } & \text { Gross domestic product } \\ \text { GHG } & \text { Greenhouse gas } \\ \text { SOC } & \text { Soil organic carbon }\end{array}$

\section{Introduction}

Producing biofuels in developing countries is a contested issue. Some view biofuels as a threat to food security and caution against local production (Runge and Senauer 2007; Molony and Smith 2010). Others see biofuels as an export opportunity, similar to traditional crops like tobacco and cotton, that could create jobs and raise incomes in rural areas (Müller et al. 2008; Pingali et al. 2008; Ewing and Msangi 2009). Studies of biofuel production in low-income countries find mixed evidence to support either view. Economic outcomes, including food security, depend on local contexts, production technologies, and institutional arrangements (Girard and Fallot 2006; Clancy 2008; Phalan 2009; Duvenage et al. 2013). In Mozambique, for example, producing feedstock on plantations generates more economic growth, whereas smallholder farming is more effective at reducing poverty, despite displacing food production (Arndt et al. 2010).

Another contested issue is biofuels' contribution to climate change mitigation. Growing feedstock can reduce greenhouse gas (GHG) emissions through soil organic carbon (SOC) sequestration, and biofuels can substitute for fossil fuels. A number of studies confirm this potential to reduce emissions (e.g., Hill et al. 2006). However, if uncultivated lands are cleared to make way for feedstock, then the carbon released may take decades to offset. In Brazil, for example, Fargione et al. (2008) finds that it would take 300 years to offset the carbon released from tropical deforestation to produce soybean-biodiesel. As with economic outcomes, the net emissions from biofuel production depend on local contexts, including farming practices and the type of land cover converted to feedstock (Andrade de Sá et al. 2012).

There is a large literature on the global effects of biofuels, including food production, land use change and GHG emissions (see, for example, Rosegrant et al. 2008; Timilsina et al. 2012; Timilsina and Mevel 2012). These studies typically focus on biofuel production in more developed countries and then consider its implications for commodity trade and prices in low-income countries. There are few country-level studies that consider the implications of local biofuels production in low-income countries. Since country studies are not constrained by global datasets, they can be more detailed than global studies and focus on the choice of technologies and production scales (see Arndt et al. 2010, 2012c; Quintero et al. 2012). To our knowledge, however, there are no country studies that quantitatively examine the joint effect of biofuels production on GHG emissions and socioeconomic outcomes. This is an important omission since many developing countries are promoting biofuels, but emissions constraints could alter their choice of technologies and institutional arrangements and, by doing so, limit biofuel's effect on economic growth, food security and poverty. It could also determine countries' access to export markets where demonstrable emissions reductions are a prerequisite, such as the European Union (EU).

In this paper we present an integrated approach to evaluating biofuels' environmental and economic impacts. We use a series of models to simulate the establishment of a sizable 
biofuels industry in Tanzania. These sequentially-linked models account for natural resource constraints; emissions from land use change; economywide growth linkages; and household poverty. The models are used to evaluate trade-offs between environmental and economic outcomes. In our simulations we consider various policy options for producing sugarcaneethanol, including production under small and large-scale farming systems and on forest, grass and already-cultivated lands.

Our findings indicate that, in the absence of emissions constraints, the economically optimal biofuels strategy for Tanzania involves smallholder farmers growing feedstock on currently unused land. Smallholder production systems lead to more poverty reduction with only a slightly smaller gain in economic growth. This is consistent with an earlier study that focused exclusively on biofuel's economic impacts in Tanzania (Arndt et al. 2012c). However, we find that there is a much larger role for large-scale plantation farming when emissions constraints are imposed. This is because large-scale farming systems are more effective at curbing emissions from land use change and maximizing economic growth, while still reducing poverty and food insecurity, albeit by less than under a smallholderoriented strategy. Climate change mitigation therefore alters the optimal biofuels strategy for Tanzania, suggesting a trade-off between environment and socioeconomic objectives.

The next section describes the Tanzanian economy and its potential for local biofuels production. We then describe the methods used to measure emissions and economic outcomes before presenting and discussing our results. The final section summarizes our findings and discusses their implications for biofuels policy and future research.

\section{Biofuels in Tanzania}

Tanzania is similar to many other low-income countries in sub-Saharan Africa. It is an agrarian economy dominated by smallholders growing food crops for subsistence. Poverty and food insecurity are concentrated in rural areas (Pauw and Thurlow 2011). Agriculture accounts for four-fifths of employment and one third of exports and gross domestic product (GDP) (Arndt et al. 2012c). A dependence on rainfed agriculture makes Tanzania vulnerable to climate change, and this exposure to weather shocks is expected to worsen in the future. For example, Arndt et al. (2012a) evaluate a range of climate projections and find that agricultural GDP could decline by as much as $11.5 \%$ by 2050 relative to a "no climate change" baseline. It is therefore in Tanzania's interest to support global climate change mitigation, especially since the country itself does not contribute much to global emissions. ${ }^{1}$

There are also economic incentives for Tanzania to produce biofuels. As with most lowincome countries, fossil fuels are a large share of the total import bill. In 2007, Tanzania imported 13.4 million barrels of fossil fuels at a cost equal to one third of total imports (World Bank 2013a). Fuel subsidies also amounted to 1.6\% of GDP in 2012 (IMF 2013). Fluctuations in oil prices therefore have macroeconomic implications. There is scope to reduce oil dependence through biofuels, especially since local fuel demand is expected to rise to 21 million barrels per year by 2015. There is also export demand arising from biofuel mandates in more developed countries (Timilsina and Mevel 2012). Finally, diversifying exports into biofuels could reduce Tanzania's vulnerability to oil price fluctuations.

Tanzania's government is preparing its national biofuels strategy, which will outline conditions for producing biofuels within the country (FAO 2010). One expected condition is

1 Tanzania generated only $0.02 \%$ of global emissions in 2010 , i.e., $0.15 \mathrm{tCO}_{2}$ eq per person compared to a global average of $4.88 \mathrm{tCO}_{2}$ eq per person (World Bank 2013a). 
Table 1 Sugarcane-ethanol production technologies
Source: Own calculations based on Arndt et al. (2012c) and Quintero et al. (2012)

\begin{tabular}{lll}
\hline & \multicolumn{2}{l}{ Sugarcane production scale } \\
\cline { 2 - 3 } & Small-scale & Large-scale \\
\hline Biofuels produced $\left(1,000 \mathrm{~m}^{3}\right)$ & 1,000 & 1,000 \\
Biofuel conversion $(1 / \mathrm{t})$ & 69.4 & 69.4 \\
Feedstock quantity $(1,000 \mathrm{t})$ & $14,406.7$ & $14,406.7$ \\
Feedstock yield (t/ha) & 42.8 & 84.0 \\
Land use (1,000 ha) & 336.6 & 171.5 \\
Workers (1,000 people) & 765.9 & 77.4 \\
Capital (1,000 units) & $1,051.7$ & $3,426.5$ \\
Fertilizer (DAP) (1,000 t) & 0.0 & 21.4 \\
Fertilizer (Urea) (1,000t) & 0.0 & 38.6 \\
Herbicides (1,000 t) & 0.0 & 2.2 \\
Area irrigated (1,000 ha) & 0.0 & 138.0 \\
Gasoline/diesel (1,000 m ${ }^{3}$ ) & 96.5 & 63.9 \\
Biofuel production cost (US\$ll) & 0.567 & 0.434
\end{tabular}

that smallholders be involved extensively in feedstock production in order to maximize the benefits for poorer farmers. However, natural resource and GHG emissions constraints might limit the policy options available to the government, especially if Tanzania intends to export biofuels to EU markets, where contributions to climate change mitigation are a prerequisite for gaining preferential access. An integrated assessment of biofuels production in Tanzania is needed in order to determine whether there are trade-offs between environment and development objectives.

Quintero et al. (2012) evaluated different options for producing biofuels in Tanzania and conclude that they can be produced profitably at expected future oil prices. Sugarcane-ethanol, for example, can be produced on large-scale plantations at US\$0.43/liter. ${ }^{2}$ Based on these findings, FAO (2010) conclude that Tanzanian ethanol is profitable at a Rotterdam delivery price of US\$70 per barrel. Although Brazil can deliver ethanol at US\$40 per barrel, Tanzania can still compete in EU markets since it is exempt from EU import tariffs (equal to US\$37 per barrel in 2010).

Table 1 shows the production technologies used in FAO (2010) to evaluate sugarcaneethanol produced under small and large-scale farming systems in Tanzania. "Small-scale" refers to vertically-coordinated outgrower schemes linking smallholder farmers to centralized feedstock collection and processing. The two scenarios use the same processing technology to produce the same volume of ethanol, i.e., one million cubic meters ( 8.4 million barrels). As such, the feedstock requirements are identical, i.e., 14.4 million tons of wet-weight sugarcane. Smallholders obtain lower yields than plantations, i.e., 42.8 versus 84.0 tons per hectare, and therefore require nearly twice as much land to produce the same amount of feedstock. Higher yields also explain why large-scale farming is more profitable. One reason for these yield differences is that smallholders rarely use improved inputs, such as fertilizer and irrigation, but instead rely on manual labor. The small-scale scenario therefore creates more jobs, but earnings per worker are lower.

Using the technologies in Table 1, Arndt et al. (2012c) estimated the economic impacts of sugarcane-ethanol production in Tanzania. The authors find that biofuel investments acceler-

2 Peters and Thielmann (2008) report ethanol production costs of US $\$ 0.60 /$ liter or US $\$ 95$ per barrel. 


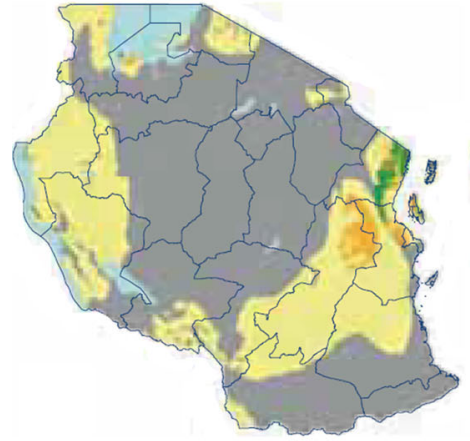

(a)

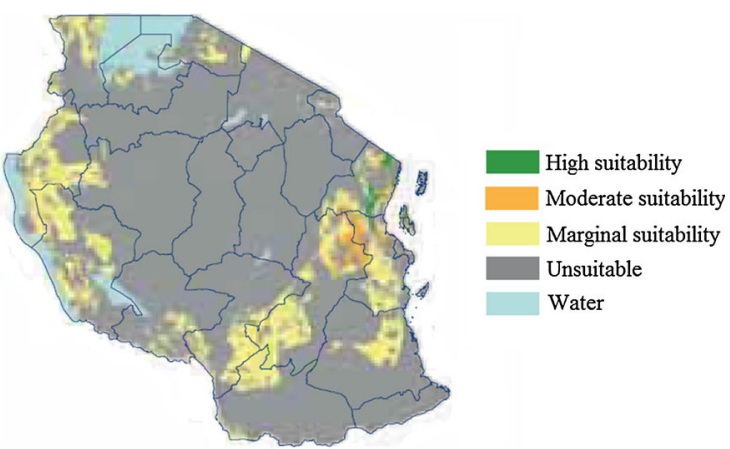

(b)

Fig. 1 a All land suitable for sugarcane and b available land suitable for sugarcane from FAO (2008). Available land excludes urban centers, nature reserves, forests and cultivated land. Suitability index is the ratio of expected to maximum attainable yield (high : $>0.6-1.0$; moderate : $>0.4-0.6$; marginal : $>0-0.4$; unsuitable: 0)

ate economic growth and reduce poverty, and that biofuels are more likely to displace export crops than food crops. In fact, food security might improve as a result of crop diversification and higher rural incomes. ${ }^{3}$ The authors conclude that, from a development perspective, the optimal biofuels strategy for Tanzania involves substantial smallholder participation in feedstock production.

A major limitation of Arndt et al. (2012c) is that they do not consider natural resource or environmental constraints. The authors assume that half of the biofuel feedstock is produced on uncultivated land and the rest is produced on smallholder crop land. This assumption is limiting for two reasons. First, emissions constraints could prevent certain land use change, particularly deforestation. Secondly, land that is suitable for growing sugarcane might be limited.

Figure 1 identifies suitable lands for sugarcane based on climate and soil conditions. "Highly suitable" land is needed to achieve the crop yields reported in Table $1 .{ }^{4}$ Investors are also more likely to be interested in contiguous lands near to coastal ports. Under these criteria, there is 878,000 ha of suitable land for sugarcane-ethanol production, all of which is within the Pwani and Tanga districts of northeast Tanzania (see FAO 2010). Of this, 507,900 ha $(58 \%)$ are already used for crop cultivation and 123,300 ha $(14 \%)$ are protected forests and urban centers. Only the remaining 246,800 ha (28\%) are uncultivated grasslands. A smallscale scenario requiring $336,600 \mathrm{~h}$ (see Table 1) will necessarily involve some deforestation or displacement of existing smallholder farming. In the next section we describe our approach to evaluating the implications of land use change and emissions constraints for biofuels production in Tanzania.

\section{Measuring Emissions and Economic Impacts}

We use a sequence of models to measure the GHG emissions and economic impacts of the small and large-scale sugarcane-ethanol scenarios shown in Table 1. We focus on these two

3 This negligible effect of biofuels on food security is specific to Tanzania. In a similar study for Mozambique it was found that food insecurity worsened as a result of biofuels production (see Arndt et al. 2010).

4 The maximum potential sugarcane yield is about $140 \mathrm{mt} / \mathrm{ha}$ (FAO 2010). Highly suitable lands achieve at least $60 \%$ of the maximum yield, which is the $84 \mathrm{mt} / \mathrm{ha}$ reported for the large-scale scenario in Table 1 . 
scenarios because they allow us to compare our findings to those from earlier studies that did not consider land use change and emissions constraints. The large biofuel production levels shown in Table 1 represent the establishment of a sizable biofuels industry in Tanzania-one that exceeds domestic fuel consumption needs and instead focuses on biofuels exports.

The computable general equilibrium (CGE) model from Arndt et al. (2012c) is used to capture economywide linkages and estimate impacts on economic growth, household welfare and poverty. We extend the authors' analysis by considering a range of land use change options. Emissions from feedstock production are measured using the EX-ACT (Ex-ante Carbon-balance Tool) model from Bernoux et al. (2010). Biofuels processing and transport emissions are estimated using the BIOTA (Bioenergy Techno-economic Analysis) model from Quintero et al. (2012). We use these models to evaluate three policy variables: (i) the scale of feedstock farming (smallholder versus plantation); (ii) the share of feedstock produced on cleared lands (from zero to a $100 \%$ ); and (iii) the type of lands that are cleared (grasslands or forests). This section describes the models and the next section presents the simulation results.

\subsection{Economywide Growth and Poverty Impacts}

Economic impacts are measured using the recursive dynamic CGE model from Arndt et al. (2012c). This allows us to generate scenarios that are consistent with earlier analysis but with additional climate and natural resource constraints. Unlike partial equilibrium models, a CGE model ensures that macroeconomic constraints are respected. This is important for our analysis since the biofuels scenarios we consider are large enough to have economywide implications. Unlike global models, country CGE models are better at capturing local economic structures and simulating the establishment of new industries. A country CGE model is thus an ideal tool for evaluating national biofuels policy in low-income countries.

The Tanzania CGE model is a detailed representation of the economy. Factor demand in each of the 58 sectors in the model is determined by a constant elasticity of substitution function under constant returns to scale. The factors of production include three educationbased labor categories (primary, secondary, and tertiary); small and large-scale crop land; local capital; and foreign capital in the biofuels sector. Composite factor and product-level intermediate inputs are combined in fixed proportions.

The model is run over the period 2007-2015. Land and labor are mobile across sectors and their total supply grows over time based on historical trends. Past investment determines new capital stocks, which are allocated to sectors according to profit-rate differentials. Once invested, capital is immobile and earns sector-specific returns. The rate of technical change is determined exogenously so that the baseline replicates historical growth patterns.

The model includes two sugarcane-ethanol sectors representing the small and large-scale technologies in Table 1. These sectors produce no biofuels in the baseline. In the biofuels scenarios, the amount of foreign capital invested in these sectors is scaled up to meet the feedstock and ethanol production levels shown in Table 1. This generates demand for labor, which, given resource constraints, must be drawn from other sectors and will involve adjustments in wage rates.

The extent to which biofuels production displaces land from existing crops depends on how much forest and grassland is cleared, which is determined exogenously in our model. When no land clearing is allowed then all feedstock is produced on already-cultivated lands and so there is maximum crop displacement. Conversely, there is no crop displacement when feedstock is grown exclusively on cleared lands. Since most farm land in Tanzania is used by smallholders, we assume that all displacement takes place on smallholder land. Although we 
exogenously determine land clearance rates in each scenario, all remaining land is allocated endogenously across non-biofuel crops based on their relative returns. Thus while our model purposefully precludes "indirect land use change", i.e., additional or unintended land clearing for non-biofuel crops, it does capture biofuels' indirect effects on the land allocation of nonbiofuel crops.

The model includes international trade and allows for imperfect substitution between domestic and foreign goods. Producers' decision to supply export markets and consumers' decision to buy imported goods are based on relative prices. All domestic, import and export prices include relevant indirect taxes and, since Tanzania is a small country, world prices are fixed. The current account balance is maintained through changes in the real exchange rate.

Following Arndt et al. (2010, 2012c), we assume that all biofuels are exported. If biofuels and imported fossil fuels are perfect substitutes and local biofuels are not taxed or subsidized differently from fossil fuels (as we assume), then there is little economic difference between Tanzania supplying biofuels to domestic markets in order to reduce demand for imported fuels; or exporting biofuels and using these revenues to pay for imported fuels. We also assume that the profits earned by foreign capital in the biofuels sector are repatriated, i.e., transferred back to the foreign investor.

The 15 representative households in the model receive incomes based on their factor endowments. Households pay taxes, save and consume goods. The latter is determined by a linear expenditure system and income elasticities are estimated using a national household budget survey. A top-down micro-simulation module measures changes in poverty (see Arndt et al. 2012b). Each household in the model is linked to its corresponding survey households. Changes in real consumption spending are passed down from the model to the survey, where total per capita consumption levels are recomputed and compared to the official poverty line.

The government receives direct and indirect taxes and uses these revenues to pay for public consumption and investment. Private, public and foreign savings (i.e., capital inflows) are pooled and used to finance investment. We assume that public consumption growth is fixed and tracks historical trends. Domestic excise tax rates on pure fossil fuels and blended fuels are identical, i.e., there is no tax or subsidy exception on domestic ethanol. Similarly, biofuels firms pay the same average corporate tax rate as existing firms. As such, any change in tax revenues derives from economic growth rather than from differential tax rates on the biofuels industry. An increase in tax revenues causes the government to reduce its borrowing, thus leading to higher private savings. This effect is quite modest in our scenarios and does not drive out results. Finally, households' savings rates are fixed and investment demand adjusts so that it equals total savings in equilibrium.

Overall, the CGE model captures many of the concerns about producing biofuels in lowincome countries. It captures land and labor resource constraints and the displacement of food crops when feedstock is grown on already-cultivated lands. There are also concerns that foreign investors are using biofuels to secure long-term leases for government-owned land in African countries (see Cotula et al. 2009). Our model reflects some of these concerns over "land-grabbing" by assuming that it is smallholder land that is displaced by biofuels and that all biofuel profits are repatriated. The model also captures the macroeconomic constraints facing any sizable expansion of biofuels production in a small economy like Tanzania.

\subsection{Emissions from Feedstock Farming and Biofuel Processing}

We use the EX-ACT and BIOTA models to estimate the GHG emissions generated by the biofuels scenarios in the CGE model. EX-ACT is a land-based accounting system that estimates changes in carbon balance (GHG emissions and carbon sequestration) from land use change 
and land management practices (see Bernoux et al. 2011; Branca et al. 2013). $\mathrm{CO}_{2}, \mathrm{CH}_{4}$ and $\mathrm{N}_{2} \mathrm{O}$ emissions are measured using the methods prescribed by the Intergovernmental Panel on Climate Change (IPCC 2006), complemented by other existing methodologies and reviews of default coefficients. EX-ACT is a generic model that is calibrated to the agro-ecological conditions of the Pwani and Tanga districts in Tanzania in order to calculate the emissions generated during feedstock farming. Table 4 in the Appendix reports the emissions factors derived from EX-ACT for our biofuels scenarios. ${ }^{5}$

Two kinds of land clearing are considered, i.e., converting either forests or grasslands to sugarcane (an annual crop). In calibrating EX-ACT, we assume that Pwani and Tanga have a "moist tropical climate", forests are "tropical shrub-lands", and the dominant soil types are "high activity clays" (i.e., Cambisol, Luisol and Vertisol; MINAG 2006). We assume that four-fifths of the forest biomass is exported and so the emissions from burning dry matter are relatively low. ${ }^{6}$ Nevertheless, EX-ACT estimates that, using default coefficients, deforestation is a potentially large source of carbon in Tanzania, generating $75.7 \mathrm{t}$ of $\mathrm{CO}_{2}$ equivalent emissions per hectare $\left(\mathrm{tCO}_{2} \mathrm{eq} / \mathrm{ha}\right)$ in the immediate year of the land use change. In contrast, emissions from grassland conversion are almost six times lower at $12.9 \mathrm{tCO}_{2} \mathrm{eq} / \mathrm{ha}$. Note that EX-ACT uses constant coefficients at all scales of production and so its emissions factors for deforestation and grassland conversion apply to both the small and large-scale scenarios in Table 1.

Most of the cultivated land in Pwani and Tanga is used to grow maize (Pauw and Thurlow 2011). This is therefore the reference crop for calculating net emissions when sugarcane displaces already-cultivated lands. Since we assume that smallholders are displaced by feedstock production, we do not include emissions from improved inputs, such as fertilizer, for the reference crop since smallholders in Tanzania rarely use improved inputs. Residual sugarcane and maize biomass are burnt each year before planting. Maize is a carbon sink absorbing $5.9 \mathrm{tCO}_{2} \mathrm{eq} /$ ha per year. ${ }^{7}$ This is higher than sugarcane, which absorbs 4.1 and $1.6 \mathrm{tCO}_{2} \mathrm{eq} / \mathrm{ha}$ per year for small and large-scale farming systems, respectively. ${ }^{8}$ This means that displacing cultivated lands generates GHG emissions.

Once harvested, sugarcane is transformed into ethanol. Processing emissions are measured using BIOTA based on the medium ("Level 2") processing technology described in Quintero et al. (2012). Processing requires energy for heating and electricity, which usually come from external sources or burning fossil fuels. Our analysis for Tanzania includes cogeneration systems that burn biomass residues. This satisfies most energy requirements and lowers production costs. Processing emissions therefore mainly come from sugar fermentation and burning biomass.

\footnotetext{
5 The technologies shown in Table 1, the assumptions in Table 4 and the discussion in this section provide the information needed to replicate our results using EX-ACT. The model distinguishes between an implementation phase, i.e., the active funding and investment phase of a project, and a capitalization phase, i.e. when benefits from the investment still occur and can be attributed to the project. To estimate general emissions factors for Tanzania from EX-ACT, we choose a 1 year immediate implementation period without a capitalization period and use default coefficients unless otherwise stated.

6 Forest products are already a major export from Tanzania and so it is likely that any timber from deforestation would be exported. To remain consistent with Arndt et al. (2012c), our analysis does not include revenues from additional forestry exports arising from deforestation. Nor does it include the costs of land conversion.

7 Maize's SOC is derived from the Soil Carbon Sequestration Database (World Bank 2013b). Our estimate of $1.61 \mathrm{tC} / \mathrm{ha} / \mathrm{year}$ is for first season maize in the Tanga district averaged over 20 years.

8 Sugarcane's SOC is derived from its carbon content (Beeharry 2001), moisture content (Pérez 1997) and other elemental components (Da Rosa 2009). Our estimate of $1.22 \mathrm{tC} /$ ha/year is consistent with the SOC of $0.73 \mathrm{tC} / \mathrm{ha} /$ year for sandy soils and $2.00 \mathrm{tC} / \mathrm{ha} /$ year for clay soils reported in Cerri et al. (2011).
} 
Table 2 Emissions per liter of ethanol in the immediate year of land use change $\left(\mathrm{kgCO}_{2} \mathrm{eq} / \mathrm{l}\right)$

\begin{tabular}{|c|c|c|c|}
\hline & \multicolumn{2}{|c|}{$100 \%$ land clearing } & \multirow[t]{2}{*}{$100 \%$ displacemen } \\
\hline & Forests & Grasslands & \\
\hline Small-scale production & 25.36 & 4.23 & 1.85 \\
\hline Deforestation/grasslands & 25.48 & 4.35 & 0.00 \\
\hline of which Soil change & 2.09 & 2.09 & 0.00 \\
\hline Crop displacement & 0.00 & 0.00 & 1.97 \\
\hline Sugarcane growing & -1.37 & -1.37 & -1.37 \\
\hline Processing and transport & 1.25 & 1.25 & 1.25 \\
\hline Large-scale production & 13.96 & 3.19 & 1.98 \\
\hline Deforestation/grasslands & 12.98 & 2.22 & 0.00 \\
\hline of which Soil change & 1.06 & 1.06 & 0.00 \\
\hline Crop displacement & 0.00 & 0.00 & 1.00 \\
\hline Sugarcane growing & -0.28 & -0.28 & -0.28 \\
\hline Processing and transport & 1.25 & 1.25 & 1.25 \\
\hline
\end{tabular}

Source: EX-ACT and BIOTA results

Displacement refers to the reallocation of land from maize to sugarcane farming

Finally, GHG emissions are generated when feedstock is transported to processing plants and ethanol is transported to distribution centers (i.e., ports and urban areas). BIOTA measures these emissions based on the mode and load of transport and the distance travelled. Based on the geography and road density of Pwani and Tanga, we assume that farmers are situated $40 \mathrm{~km}$ from processing plants and that distribution centers are a further $250 \mathrm{~km}$ away. ${ }^{9}$ Used together, the EX-ACT and BIOTA models allow us to measure the emissions generated throughout biofuel's entire production chain.

\section{Simulation Results}

Three policy options are considered: (i) small versus large-scale feedstock farming; (ii) the extent of land clearing; and (iii) clearing of forest versus grassland. Emissions results are presented first, followed by economic impacts, and then the interaction between these outcomes.

\subsection{Emissions from Land Use Change and Biofuels Processing}

We start by discussing emissions that are generated in the first year of the land use change, and then discuss how average emissions change over time as more ethanol is produced. Table 2 shows the results from EX-ACT and BIOTA for scenarios in which sugarcaneethanol is produced entirely on forest, grass or already-cultivated lands. Emissions are highest for deforestation. Ethanol produced using small-scale farmers generates 25.4 kilograms of $\mathrm{CO}_{2}$-equivalent emissions per liter $\left(\mathrm{kgCO}_{2} \mathrm{eq} / \mathrm{l}\right)$ in the initial year. This is much higher than

9 Sensitivity analysis indicates that reallocating these distances has little effect on emissions per liter of ethanol. 
the emissions from burning gasoline, which the IPCC (2006) estimates at $2.85 \mathrm{kgCO}_{2} \mathrm{eq} / \mathrm{l} .{ }^{10}$ Emissions are almost halved under large-scale farming systems because yields are higher and so less forest is cleared. However, even large-scale emissions from deforestation are almost five times higher than the "neutral emissions" threshold (i.e., gasoline's emissions factor). Emissions under grassland conversion are lower, but still fall short of being emissions-neutral.

Note that we adopt a technical definition of "emission neutrality", i.e., zero net emissions relative to fossil fuels. However, in order to meet the sustainability criteria for accessing EU markets, biofuels must reduce emissions by at least $35 \%$ relative to fossil fuels (Scarlat and Dallemand 2011). This implies a maximum of about $1.85 \mathrm{kgCO}_{2} \mathrm{eq} / 1$ (i.e., $0.65 \times 2.85)$. Moreover, these criteria become more binding over time, with the threshold falling to $1.14 \mathrm{kgCO}_{2} \mathrm{eq} / \mathrm{l}$ by 2020 . Our emissions constraint is therefore less stringent than in Tanzania's most likely export market.

Table 2 decomposes the sources of emissions. The SOC sequestered from small-scale sugarcane more than offsets the emissions from biofuel processing and transport (i.e., $\left.1.25 \mathrm{kgCO}_{2} / \mathrm{l}\right)$. This is not the case for large-scale sugarcane since less land is needed to produce one liter of ethanol and so there is less sequestered SOC. Large-scale farmers also generate additional emissions from improved input use. Note that emissions from biofuel processing are constant across scenarios since the same amount of sugarcane is processed irrespective of the amount or type of land that is cleared.

The final column of Table 2 shows that there is an increase in net emissions when sugarcane is grown on land that is already cultivated (i.e., displaced smallholder land). This is because the reference crop, maize, has greater SOC than sugarcane (see Table 4 in the Appendix), and so replacing maize with sugarcane reduces sequestration. However, net emissions per liter of ethanol produced on already-cultivated lands are below gasoline's emissions factor. These emissions are lower for small-scale production because smallholders do not use improved inputs, such as fertilizer.

Clearing forests and grassland incurs a once-off loss in biomass. Average emissions per liter of ethanol fall over time as biofuel production continues and the initial biomass loss is divided over a larger volume of ethanol. ${ }^{11}$ Figure 2 shows how average emissions per liter of ethanol produced on forest and grassland decline in the years following the initial land use change. Emissions are cumulative, which means that the carbon payback period is reached when average emissions falls below $2.85 \mathrm{kgCO}_{2} \mathrm{eq} / \mathrm{l}$. From this point onwards, biofuels have reduced emissions relative to gasoline.

The "carbon payback period" is defined here as the number of years needed to reach emissions-neutrality by using biofuels instead of burning gasoline. The carbon payback period for sugarcane-ethanol produced on converted grasslands is 2-3 years depending on the scale of farming. In contrast, sugarcane-ethanol produced on deforested lands has a much longer carbon payback period of 15-27 years, even though we assume that most of the forest biomass is exported rather than burned locally. These results indicate that it is possible for Tanzania to contribute to climate change mitigation by producing biofuels that can replace fossil fuels, although this depends crucially on land use change and the timeframe for carbon accounting. The EU's sustainability criteria impose a 20-year threshold for demonstrating net emissions reductions (Scarlat and Dallemand 2011). This criterion alone means that some production options are unavailable to Tanzania if it intends to export to EU markets.

10 Table 2 reports a combined emissions factor for gasoline and diesel, which is lower at $2.63 \mathrm{kgCO} 2 \mathrm{eq} / \mathrm{liter}$. Since ethanol is blended with gasoline we compare our emissions factors to those of gasoline only.

11 Table 4 in the Appendix identifies once-off and recurring emissions. 


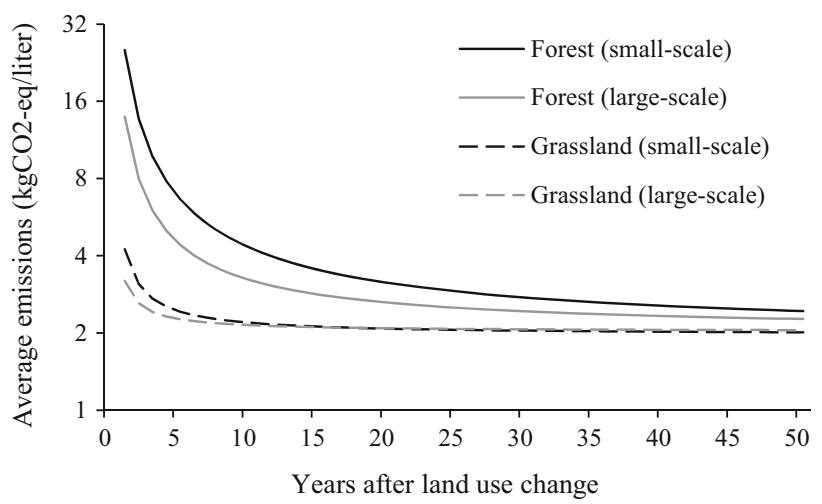

Fig. 2 Average emissions per liter of ethanol produced entirely on forest or grassland and under small and large-scale farming systems

Average emissions per liter of ethanol eventually stabilize at about $2.0 \mathrm{kgCO}_{2} \mathrm{eq} / \mathrm{l}$. At this point the emissions from land clearing are spread out across a long enough time period that their contribution to average emissions approaches zero. Average emissions per liter are then equal to emissions from growing sugarcane and the foregone SOC sequestration from cleared and displaced lands. For example, drawing on Table 2, the emissions from large-scale sugarcane-ethanol grown on grasslands stabilize at $2.04 \mathrm{kgCO}_{2} \mathrm{eq} / \mathrm{l}$, which is the sum of foregone grassland SOC sequestration (+1.06) and emissions from growing sugarcane $(-0.28)$ and processing ethanol $(+1.25)$. This is below the neutral-emissions threshold, but well above the EU's $1.14 \mathrm{kgCO}_{2} \mathrm{eq} / 1$ threshold planned for 2020 . This is also true for sugarcane-ethanol produced on displaced smallholder lands, whose emissions remain constant at 1.85 and $1.98 \mathrm{kgCO}_{2} \mathrm{eq} / \mathrm{l}$ for small- and large-scale production, respectively (see Table 2). Therefore, even without clearing forests or grasslands, Tanzania will need to reduce emissions, particularly from processing biofuels, in order to meet the EU threshold.

\subsection{Economic Growth and Household Welfare Effects}

Economic outcomes depend on total changes in land supply and not on the type of land that is cleared. Table 3 reports the results from the CGE model—shown as deviations from a "no biofuels" baseline. Arndt et al. (2012c) assume that $50 \%$ of feedstock is produced on cleared lands. We drop this assumption and simulate the full range of land clearing rates from 0 to $100 \%$. In this section we contrast the two extreme scenarios.

Biofuels production increases GDP at factor cost. Growth effects are larger under largescale farming systems and with $100 \%$ land clearing. Three factors explain this gain in GDP. First, clearing land increases total land availability and expands Tanzania's production possibility frontier. This effect is largest when more lands are cleared, i.e., under small-scale farming. Foreign direct investment in the biofuel sectors also expands Tanzania's productive capacity, but this investment is independent of the amount of land that is cleared. Since plantations are more capital-intensive than smallholder farms, they require more foreign investment and less land. This explains why there is less variation in economic outcomes across land clearing rates for large-scale production. ${ }^{12}$

12 We assume that the capital and incentives required to clear lands are the result of foreign direct investment (FDI) and that investors are only interested in biofuels. As such, the FDI funds and cleared lands are not 
Table 3 Socioeconomic impacts of biofuels scenarios

\begin{tabular}{|c|c|c|c|c|}
\hline & \multicolumn{4}{|c|}{ Deviation from final year baseline outcome $(\%)$} \\
\hline & \multicolumn{2}{|l|}{ Small-scale } & \multicolumn{2}{|l|}{ Large-scale } \\
\hline & $100 \%$ clearing & $0 \%$ clearing & $100 \%$ clearing & $0 \%$ clearing \\
\hline Total GDP & 3.08 & 2.51 & 4.08 & 3.80 \\
\hline Agriculture & 2.69 & 1.20 & 3.59 & 2.83 \\
\hline Non-agriculture & 3.27 & 3.14 & 4.20 & 4.14 \\
\hline Food production & 0.67 & -1.15 & 1.44 & 0.52 \\
\hline Real food prices & 0.43 & 0.89 & -0.16 & 0.07 \\
\hline Rural welfare & 3.92 & 3.06 & 3.69 & 3.26 \\
\hline Rural poverty rate & -1.57 & -1.03 & -1.07 & -0.84 \\
\hline Rural poor (1,000 people) & -491.1 & -322.5 & -335.1 & -261.9 \\
\hline
\end{tabular}

Source: CGE results.

Simulations are run over 2007-2015. Poverty rate is the share of the national population whose per capita consumption is below the official poverty line. Welfare is measured using equivalent variation

Second, on average, sugarcane is more profitable and generates more value-added than existing crops, and so the switch to sugarcane raises GDP. Similarly, sugarcane's land-labor ratio is higher than existing crops' and so reallocating land to sugarcane "releases" labor to other sectors. This effect is largest on plantations, since they are less labor-intensive and more productive than smallholders.

Finally, biofuels stimulates growth in the rest of the economy by using other sectors' products or raising private incomes and consumption. The overall growth effect depends on the strength of biofuels' linkages relative to the displaced sectors. Food crops have strong production linkages to processing sectors and consumers, and as a result, have larger economywide growth linkages than export crops in Tanzania (Pauw and Thurlow 2011). Displacing food crops would therefore weaken agricultural growth linkages. However, as Arndt et al. (2012c) explain, expanding biofuel exports in Tanzania encourages a real exchange rate appreciation that reduces the competitiveness of traditional export crops. As such, it is export crops, rather than food crops, that are displaced by biofuels in Tanzania, and so the net effect on growth linkages is fairly modest. ${ }^{13}$ The one exception is for small-scale farming, when the demand for feedstock land is large enough to displace export crops, as well as some food crops. Most export crops in Tanzania are grown outside Pwani and Tanga, and so the model results imply that farmers in other districts switch from export to food crops. Consumers in Pwani and Tanga become more reliant on domestic food markets.

Table 3 reports changes in welfare and poverty. Welfare is measured using "equivalent variation", which controls for changes in prices, and the poverty rate is the share of the population with per capita consumption below the poverty line. Biofuels production increases rural welfare and reduces rural poverty. Involving smallholders in feedstock production generates larger welfare improvements and poverty reduction. This is because smallholder farmers are

available for non-biofuel uses in the baseline. This reflects the fact that Tanzania is often a passive recipient of FDI, i.e., foreign investors select Tanzania, not vice versa. We also assume that the profitable biofuels technology is embodied within FDI and so no biofuels can be produced in the baseline.

13 This outcome depends on local contexts. In Mozambique, for example, where traditional export crops are less important than in Tanzania, producing biofuels causes food crop production to decline (see Arndt et al. 2010). 
poorer to begin with than other rural households. A smallholder approach spreads the benefits from biofuels across a larger number of poorer households, whereas a plantation approach generates larger income gains but for fewer households. Although not shown, biofuels also reduces urban poverty, by raising wages and demand for urban products.

\subsection{Trade-Offs Between Emissions and Economic Outcomes}

In this final section we consider how emissions and economic outcomes interact with each other to constrain biofuel policy options. The top panel in Fig. 3 shows emissions per liter of ethanol produced using smallholder farmers and after the first year of the land use change. The figure reflects the full range of possible land use changes. Emissions per liter rise as more land is cleared (horizontal axis) and as more of the clearing takes place in forests (vertical axis). The lower panel shows economic impacts at different land clearing rates.

There is only a small range of land clearing options in which the ethanol produced is emissions-neutral in the initial year of the land use change (i.e., $2.85 \mathrm{kgCO}_{2} \mathrm{eq} / \mathrm{l}$ ). If only forests are used to grow sugarcane, then a maximum of $4 \%$ of the feedstock can be produced on cleared lands for the ethanol to be emissions-neutral. At this land clearing rate, biofuels production causes agricultural GDP and rural welfare to rise by 1.26 and $3.17 \%$, respectively, and rural poverty to fall by $1.08 \%$ (i.e., point $F$ in Fig. 3b). Conversely, the maximum land clearing rate for grasslands is $42 \%$ and so the maximum economic benefits are larger (i.e., point $G$ ). If ethanol produced in Tanzania is required to be emissions-neutral from the outset, then this will reduce permissible land clearing rates and limit economic benefits.

Emissions per liter decline over time and increase the range of emissions-neutral land clearing options. For example, ethanol produced using smallholders on grasslands becomes emissions-neutral 3 years after clearing. At this point it would, in principal, be possible to grow all sugarcane on cleared grassland and still reduce emissions relative to gasoline. In practice, however, there are natural resource constraints that preclude this option. The dotted areas in Fig. 3a show land clearing options that are infeasible because they exceed the total amount of forest and grassland in the Pwani and Tanga districts. Therefore, even after the carbon payback period is reached there are still limits to grassland clearing rates (i.e., $73 \%$ in Fig. 3a) and economic benefits (i.e., point $N$ in Fig. 3b).

Figure 4 shows the range of emissions and economic outcomes for large-scale production. There are two notable differences from Fig. 3. First, higher crop yields mean that a larger share of feedstock can be produced on cleared lands and still remain emissions-neutral (i.e., $72 \%$ ). Second, smaller land requirements mean that natural resource constraints are only binding for forests and at high land clearing rates. Therefore, after 2 years it is possible to produce emissions-neutral ethanol by growing all feedstock via large-scale plantations on converted grasslands.

Finally, we consider how the optimal mix of small and large-scale production is affected by natural resource and emissions constraints. Given deforestation's long carbon payback period, we focus on grasslands. Figures 3 and 4 indicated the level of grassland clearing at which ethanol is emissions-neutral immediately after land conversion. The threshold grassland clearing rates for small and large-scale production are 42 and $72 \%$, respectively. Figure 5 shows how economic outcomes vary with the share of feedstock produced by smallholders. The darker lines impose the emission-neutral land clearing thresholds, and the lighter lines do not impose any emissions constraints. The gap between the lines is the economic impact of imposing an immediate emissions constraint on Tanzanian ethanol.

Without emissions constraints there is a strong incentive to increase the participation of smallholders in feedstock production in order to increase rural welfare and reduce poverty. 


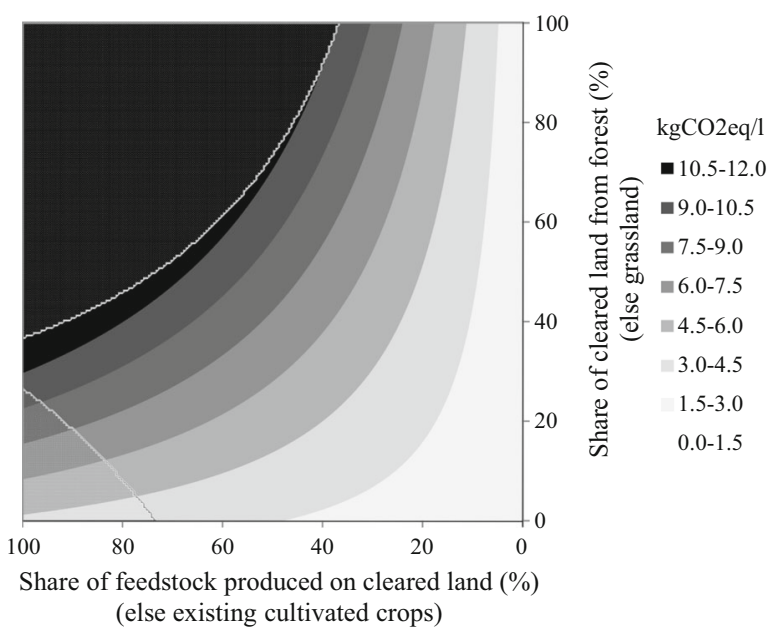

(a)

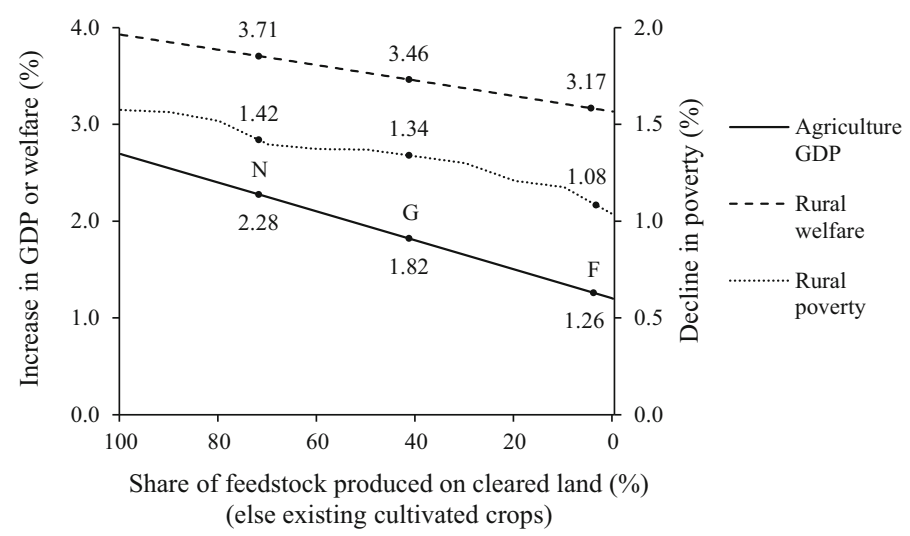

(b)

Fig. 3 a Emissions per liter of ethanol in the year after land use change and $\mathbf{b}$ change in agricultural GDP and rural poverty for sugarcane ethanol produced via a smallholder out-grower scheme. Gridded areas exceed maximum available grassland and forest areas. G and F are the maximum GDP and poverty changes for "emissions-neutral" production from converting entirely grassland or forests, respectively, and $\mathrm{N}$ is the maximum given land resource constraints.

This is consistent with conclusions reached by earlier studies (Arndt et al. 2012c). However, there is less of an incentive to involve smallholders when emissions constraints are imposed. Agricultural GDP losses are more pronounced, rural welfare now declines slightly, and the difference in poverty reduction is more than halved. This is because the emissions constraints are initially more restrictive for small-scale production, which requires more land clearing and incurs a large initial carbon debt. Over time the emissions constraints become less binding because average emissions per liter of ethanol produced decline (i.e., the darker lines tend shift towards the lighter lines). However, the limited availability of grasslands imposes an additional constraint on the economic benefits of involving smallholders. These results suggest that, under emissions constraints, there is a greater role for plantation farming systems than is suggested by studies that only focus on biofuel's economic benefits. 


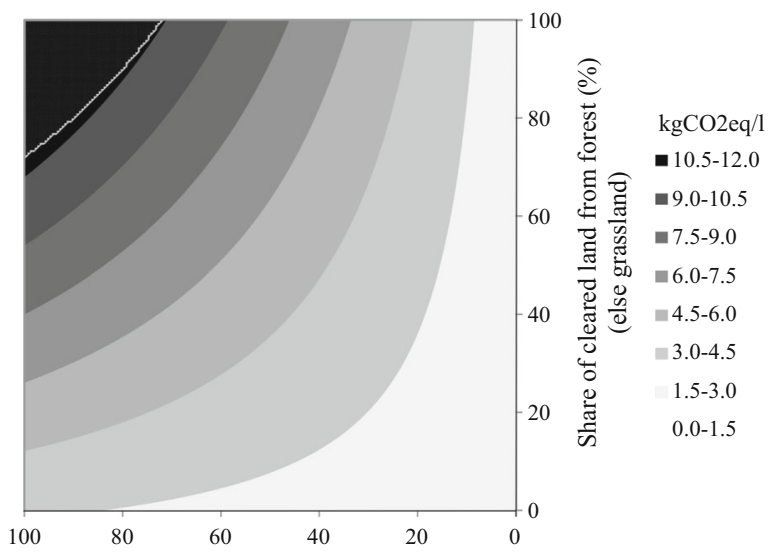

Share of feedstock produced on cleared land (\%) (else existing cultivated crops)

(a)

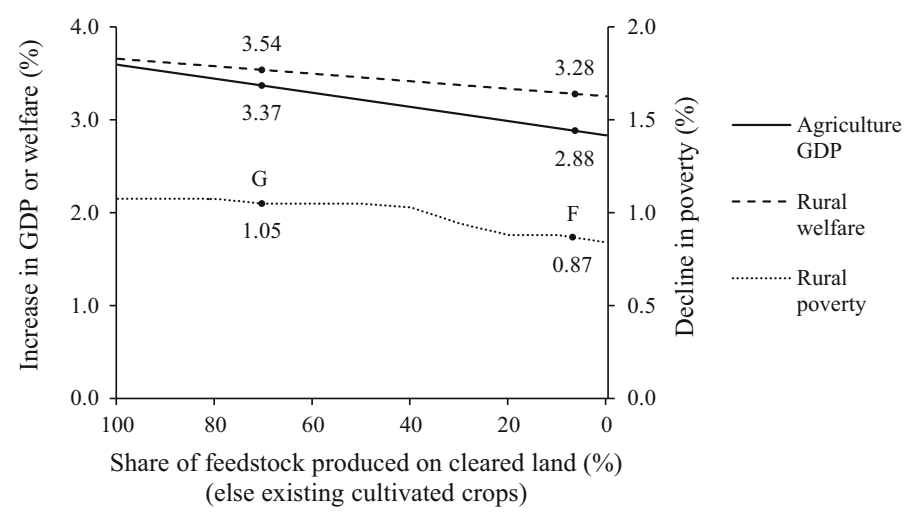

(b)

Fig. 4 a Emissions per liter of ethanol in the year after land use change and $\mathbf{b}$ change in agricultural GDP and rural poverty for sugarcane ethanol produced via plantation production. Dotted areas exceed maximum available grassland and forest areas. G and F are the maximum GDP and poverty changes for "emissionsneutral" production from converting entirely grassland or forests, respectively

\section{Conclusion}

We have developed an integrated approach to assessing the joint emissions and economic benefits from producing biofuels. This approach is well-suited to low-income country contexts, where biofuels industries have not yet been established, but whose governments are in the process of designing national biofuels strategies. We applied the approach to Tanzania, a typical low-income African country.

We used three sequentially-linked models to capture natural resource constraints; GHG emissions from land use change; economywide linkages; and household poverty. Results from the CGE model indicate that there are economic incentives to clear lands for sugarcaneethanol production. Land conversion increases the benefits of biofuels for economic growth and rural poverty reduction. However, the EX-ACT and BIOTA models estimate that the 


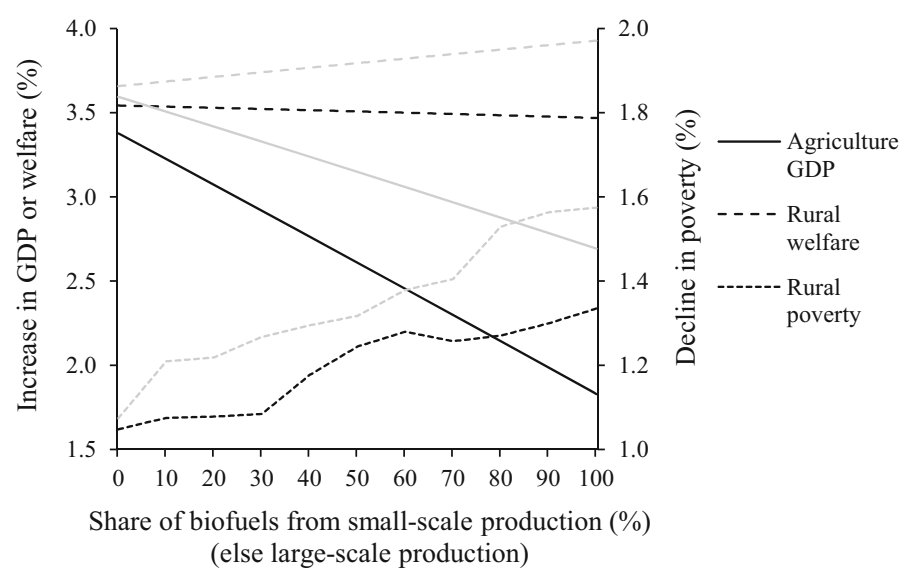

Fig. 5 Maximum changes in agricultural GDP and rural welfare and poverty for sugarcane ethanol production. Darker lines impose a neutral emissions constraint in the year of land clearing $(2.85 \mathrm{kgCO} 2 \mathrm{eq} / 1)$ by protecting forests and restricting grassland conversion rates. Lighter lines do not impose any emissions constraints (i.e., all production is on converted forest or grassland)

carbon payback period for sugarcane-ethanol produced on forest lands is 15-27 years depending on the farming system used. Payback periods are only 2-3 years for converted grasslands. This suggests that, while land clearing may be desirable, deforestation is not a viable option if Tanzania is to contribute to global climate change mitigation.

Natural resource and emissions constraints alter the optimal mix of small and large-scale farming systems. There is a strong economic incentive to use smallholders to produce feedstock, since this approach is more effective at enhancing welfare and poverty reduction. However, smallholders obtain lower yields and require more land clearing. Smallholder outgrower schemes therefore face more binding natural resource and emissions constraints, especially if feedstock is grown on forest lands. These constraints are less binding for large-scale plantations due to their higher yields and smaller land requirements. Emissions constraints therefore dampen the relative merits of a smallholder-based biofuels strategy. Our results indicate that a mixed farming system, with greater emphasis on large-scale plantations, is more appropriate when climate constraints and economic benefits are jointly considered. This is especially true if Tanzania must demonstrate significant emissions reductions in order to maintain preferential access and competitiveness in EU biofuel markets.

There are at least five areas where our analysis could be usefully extended. First, we used IPCC estimates in our EX-ACT analysis. While we consider our conclusions robust, our emissions analysis could be further refined using country-specific coefficients. Second, we did not consider non-land natural resources, such as water and biodiversity, which could impose additional constraints on biofuels policy. Third, our economic analysis ignored land clearing costs, although these may be less important once spread over the life-span of biofuels production. We also did not consider the opportunity costs of possible biofuel subsidies and public spending to support foreign biofuel investments (Peters and Thielmann 2008). Fourth, like most studies, we conducted "with" and "without biofuels" counterfactual analysis. An alternative approach would compare biofuels to other investment options. For example, a Mozambique study finds that growth in cereal crops reduces poverty more than growth in sugarcane-ethanol (Thurlow 2012). In this case, cleared lands and public resources might be better allocated to cereal crops. Of course, other options may not attract as much foreign 
investment as biofuels and may require more public investment instead. Finally, we did not include climate change impacts in our analysis. Arndt et al. (2012a) estimate that climate change will reduce Tanzania's agricultural GDP. If biofuels contributes to global mitigation, then a portion of the avoided climate damages should ideally be added to biofuel's benefits.

\section{Appendix}

See Table 4.

Table 4 Emission factors derived from EX-ACT

\begin{tabular}{|c|c|c|c|}
\hline & Factor & & Assumptions \\
\hline Deforestation ( $\left.\mathrm{tCO}_{2} \mathrm{eq} / \mathrm{ha}\right)$ & 75.69 & & Tropical shrub-land \\
\hline Biomass loss & 85.76 & & $80 \%$ dry matter exported \\
\hline Biomass gain & -18.33 & & \\
\hline Soil $\mathrm{CO}_{2}$ change & 6.20 & $*$ & Conversion to annual crop use \\
\hline Burning before land conversion & 2.06 & & $20 \%$ dry matter burned \\
\hline Grassland clearing $\left(\mathrm{tCO}_{2} \mathrm{eq} / \mathrm{ha}\right)$ & 12.94 & & Conversion to annual crop use \\
\hline Biomass loss & 5.28 & & \\
\hline Soil $\mathrm{CO}_{2}$ change & 6.20 & $*$ & \\
\hline Burning before land conversion & 1.46 & & \\
\hline Sugarcane growing $\left(\mathrm{tCO}_{2} \mathrm{q} / \mathrm{ha}\right)$ & -1.60 & & Large-scale (small-scale is -4.07) \\
\hline Soil $\mathrm{CO}_{2}$ change & -4.47 & $*$ & $1.22 \mathrm{tC} / \mathrm{ha} /$ year soil organic carbon \\
\hline Burning before planting & 0.33 & $*$ & $5.2 \mathrm{t} / \mathrm{ha}$ dry matter is burned \\
\hline Fertilizer and herbicide use & 1.51 & $*$ & IPCC emission factors \\
\hline Irrigation & 0.07 & $*$ & Installation of irrigation systems \\
\hline Gasoline/diesel use $\left(\mathrm{tCO}_{2} \mathrm{q} / \mathrm{m} 3\right)$ & 2.63 & $*$ & IPCC emission factor \\
\hline Reference crop growing ( $\left.\mathrm{tCO}_{2} \mathrm{q} / \mathrm{ha}\right)$ & -5.86 & & Weighted by existing land use \\
\hline Soil $\mathrm{CO}_{2}$ change & -5.91 & $*$ & $1.61 \mathrm{tC} / \mathrm{ha} /$ year soil organic carbon \\
\hline Burning before planting & 0.05 & $*$ & $0.8 \mathrm{t} /$ ha dry matter is burned \\
\hline
\end{tabular}

Source: EX-ACT results.

Emissions are for the initial year of land use change. An asterisk $(*)$ indicates that emissions accrue annually (others occur only at the time of land use change)

\section{References}

Andrade de Sá S, Palmer C, Engel S (2012) Ethanol production, food and forests. Environ Resour Econ 51(1):1-21

Arndt C, Benfica R, Tarp F, Thurlow J, Uaiene R (2010) Biofuels, growth and poverty: a computable general equilibrium analysis for Mozambique. Environ Dev Econ 15(1):81-105

Arndt C, Farmer W, Strzepek K, Thurlow J (2012a) Climate change, agriculture and food security in Tanzania. Rev Dev Econ 16(3):378-393

Arndt C, Hussain MA, Jones ES, Nhate V, Tarp F, Thurlow J (2012b) Explaining the evolution of poverty: the case of Mozambique. Am J Agric Econ 94(4):854-872

Arndt C, Pauw K, Thurlow J (2012c) Biofuels and economic development: a computable general equilibrium analysis for Tanzania. Energy Econ 34(6):1922-1930

Beeharry PR (2001) Carbon balance of sugarcane bioenergy systems. Biomass Bioenergy 20(5):361-370 
Bernoux M, Branca G, Carro A, Lipper L, Smith G, Bockel L (2010) Ex-ante greenhouse gas balance of agriculture and forestry development programs. Sci Agric 67(1):1-127

Bernoux M, Tinlot M, Bockel L, Branca G, Gentien A (2011) EX-ante carbon-balance tool (EX-ACT): technical guidelines for Version 3, Easypol module 101. Food and Agriculture Organization of the United Nations, Rome

Branca G, Hissa H, Benez MC, Medeiros K, Lipper L, Bernoux M (2013) Capturing synergies between rural development and agricultural mitigation: application of the Ex-ante carbon-balance tool (EX-ACT) in Brazil. Land Use Policy 30:507-518

Cerri CC, Galdos MV, Maia SMF, Bernoux M, Feigl BJ, Powlson D, Cerri CEP (2011) Effect of sugarcane harvesting systems on soil carbon stocks in Brazil: an examination of existing data. Eur J Soil Sci 62(1):23-28

Clancy JS (2008) Are biofuels pro-poor? Assessing the evidence. Eur J Dev Res 20(3):416-431

Cotula L, Vermeulen S, Leonard R, Keely J (2009) Land grab or development opportunity? Agricultural investment and international land deals in Africa. Food and Agriculture Organization, International Fund for Agricultural Development, and International Institute for Environment and Development, Rome

Da Rosa AV (2009) Fundamentals of renewable energy processes, 2nd edn. Academic Press, Boston

Duvenage I, Langston C, Stringer LC, Dunstan K (2013) Grappling with biofuels in Zimbabwe: depriving or sustaining societal and environmental integrity? J Clean Prod 42:132-140

Ewing M, Msangi S (2009) Biofuels production in developing countries: assessing tradeoffs in welfare and food security. Environ Sci Policy 12(4):520-528

FAO (2010) Bioenergy and food security: the BEFS analysis for Tanzania. Environment and Natural Resource Management Working Paper 35. Food and Agriculture Organization of the United Nations, Rome

Fargione F, Hill J, Tilman D, Polasky S, Hawthorne P (2008) Land clearing and the biofuel carbon debt. Science 319:1235-1238

Girard P, Fallot A (2006) Review of existing and emerging technologies for the production of biofuels in developing countries. Energy Sustain Dev X(2):92-108

Hill J, Nelson E, Tilman D, Polasky S, Tiffany D (2006) Environmental, economic, and energetic costs and benefits of biodiesel and ethanol biofuels. Proc Natl Acad Sci 103(30):11206-11210

IMF (2013) Energy subsidy reform in Sub-Saharan Africa: experiences and lessons. African Department, International Monetary Fund, Washington

IPCC (2006) Guidelines for national greenhouse gas inventories. In: Eggleston HS, Buendia L, Miwa K, Ngara T, Tanabe K (eds) Agriculture, forestry and other land use, vol 4. Institute for Global Environmental Strategies, Kanagawa

MINAG (2006) Soils of Tanzania and their potential for agriculture development. Mlingano Agricultural Research Institute, Ministry of Agriculture, Food Security and Cooperatives, Tanga

Molony T, Smith J (2010) Biofuels, food security and Africa. Afr Aff 109(436):489-498

Müller A, Schmidhuber J, Hoogeveen J, Pasquale Steduto (2008) Some insights in the effect of growing bio-energy demand on global food security and natural resources. Water Policy 10(S1):83-94

Pauw K, Thurlow J (2011) Agricultural growth, poverty and nutrition in Tanzania. Food Policy 36(6):795-804

Pérez R (1997) Chapter 3 Sugarcane: feeding pigs in the tropics. Food and Agriculture Organization of the United Nations, Rome

Peters J, Thielmann S (2008) Promoting biofuels: implications for developing countries. Energy Policy 36:1538-1544

Phalan B (2009) The social and environmental impacts of biofuels in Asia: an overview. Appl Energy 86(1):S21-S29

Pingali P, Raney T, Wiebe T (2008) Biofuels and food security: missing the point. Appl Econ Perspect Policy 30(3):506-516

Quintero JA, Cardona CA, Felix E, Moncada J, Sánchez OJ, Gutiérrez LF (2012) Techno-economic analysis of bioethanol production in Africa: Tanzania case. Energy 48(1):442-454

Rosegrant MW, Zhu T, Msangi S, Sulser T (2008) Global scenarios for biofuels: impacts and implications. Appl Econ Perspect Policy 30(3):495-505

Runge CF, Senauer B (2007) How biofuels could starve the poor. Foreign Aff 86(3):41-54

Scarlat N, Dallemand J-F (2011) Recent developments of biofuels/bioenergy sustainability certification: a global overview. Energy Policy 39(3):1630-1646

Thurlow J (2012) Mozambique. In: Diao X, Thurlow J, Benin S, Fan S (eds) Strategies and priorities for African agriculture: economywide perspectives from country studies. Washington, International Food Policy Research Institute

Timilsina GR, Mevel S (2012) Biofuels and climate change mitigation: a CGE analysis incorporating land-use change. Environ Resour Econ. doi:10.1007/s10640-012-9609-8 
Timilsina GR, Beghin JC, van der Mensbrugghe D, Mevel S (2012) The impacts of biofuels targets on land-use change and food supply: a global CGE assessment. Agric Econ 43(3):315-332

World Bank (2013a) World Development Indicators. data.worldbank.org/data-catalog/world-developmentindicators: last accessed March 2013

World Bank (2013b) Soil Carbon Sequestration Geodatabase. http://www-esd.worldbank.org/SoilCarbon Sequestration: last accessed March 2013 